\title{
INVESTIGATING TEACHERS’ PERCEPTIONS OF THEIR OWN PRACTICES TO IMPROVE STUDENTS' CRITICAL THINKING IN SECONDARY SCHOOLS IN SAUDI ARABIA
}

Dr. Mohammed Almulla, Department of Curriculum and Instruction, Faculty of Education, University of King Faisal, Saudi Arabia

E-mail: maalmulla@kfu.edu.sa

\section{ART I C LE INFO}

Original Research

Received: September, 28.2018.

Revised: November, 11.2018.

Accepted: November, 23.2018.

doi:10.5937/ijcrsee1803015A

UDK

$159.955 .072-057.874(532)$

$371.13(532)$

Keywords:

Critical thinking ability,

Teaching practices,

Students,

Secondary schools.

\section{A B S T R A C T}

This study aims to investigate teachers' perceptions of strategies they adopt to help their learners develop their critical thinking skills and how coherent their classroom practices are with their perceptions. The study was conducted with teachers in secondary schools in Saudi Arabia. Primary data in the form of questionnaire results, classroom observation notes and interviews was gathered to attain this goal. A total of three all-male schools participated in the study with 82 teachers completing the questionnaire, and 12 teachers (four from each school) being interviewed and observed during their classroom work. The findings suggest that positing open-ended questions to the class, focusing on performance tasks, and comparing and contrasting different perspectives were the most beneficial teaching strategies to foster students' critical thinking skills. The findings also highlight that these capabilities are affected not only by the teaching practices, but also by other factors related to the broader academic environment, such as school resources. The results of the present study may help secondary teachers to select and implement teaching strategies and consider factors that may lead to an improvement in students' critical thinking skills. While this study focuses exclusively on teachers working in the secondary schools in Saudi Arabia, some of the findings can be potentially transferable to other similar educational contexts.

(C) 2018 IJCRSEE. All rights reserved.

\section{INTRODUCTION}

Critical thinking is believed to be one of the crucial skills that should be taught to students in academic settings (Hooks, 2010). This is rationalised by the fact that critical thinking not only improves the overall degree of information acquisition - and therefore students' cognitive abilities (Tsankov, 2017) - but also augments the degree to which students are able to scrutinise knowledge related to particular and diverse disciplines, such as English language, history and biology (Hooks, 2010). However, despite the importance of this con-

Corresponding Author

Dr. Mohammed Almulla, Department of Curriculum and Instruction, Faculty of Education, University of King Faisal, Saudi Arabia

E-mail: maalmulla@kfu.edu.sa

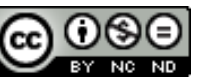

This work is licensed under a Creative Commons Attribution - NonCommercial - NoDerivs 4.0. The article is published with Open Access at www.ijcrsee.com cept, the existing body of knowledge regarding the most helpful teaching practices to enable the development of critical thinking skills is still comparatively limited when compared to other aspects related to teaching, such as motivation or assessment. For instance, the outlined problem was partially addressed in the works of authors such as Brookfield (2012), Smith et al. (2018) and Larsson (2017). Nonetheless, these studies lacked an in-depth examination of why and how the specific teaching methods and initiatives affected the critical thinking capabilities of the students (Brookfield, 2012). This lack of insight into teachers' classroom practices and strategies to promote critical thinking is addressed in the current study.

Teaching critical thinking presents a significant challenge in environments undergoing radical changes in their academic practices and policies. Saudi Arabia can be considered an example of a context going through such changes. Significant efforts have been made in Saudi Arabia to bring it in line with other 
countries where there have been changes in the educational approaches; an example of this is the introduction of new technologies and the use of social networks to facilitate teaching and learning. However, the governmental bodies in Saudi Arabia still hold considerable administrative control over all aspects of the national education system and this has sometimes negatively affected the quality and the development of educational practices in a variety of levels (Algarfi, 2010). The approach to education in the country is still largely characterised as 'traditional' since memorisation of textbooks remains the most common teaching and learning practice. According to Algarfi (2010), this is one of the main reasons behind the lack of self-criticism in the Saudi society. Posing 'why-questions' is still seen as form of rebellion and generally considered culturally inappropriate, negative, and prone to generate uneasiness among individuals. Al Lily (2018) argues that in the Saudi society, it is a 'norm' or even a 'value' not to acknowledge the negative aspects and the weaknesses of their society. In other words, it seems there is a widely spread belief that it is okay to make a sin, as long as you do not admit it and do not talk about it.

Alaqeel (2013) establishes that helping students think critically and develop their skills in observation and analysis is one of the main aims of secondary school education. Although there are studies conducted in Saudi Arabia that acknowledge the importance of teaching students critical thinking skills and training teachers to implement strategies to attain this goal (Alghamdi et al., 2013; Allamnakhrah, 2013; Alwadai, 2014), there are still very few studies that aimed to investigate effective and useful teaching practices that may promote the development of learners' critical thinking skills. The findings of this study may help teachers to decide on the most useful teaching practices to enable the development of critical thinking skills and positively affect students' learning.

According to Aldiab et al. (2017) and Alothman et al. (2017), there exists a substantial drive for the implementation of new teaching technologies and innovative teaching practices in the Saudi Arabian academic sector. In addition, the government of Saudi Arabia has recently initiated a large-scale educational reform project aimed at improving the school curricula and teaching competencies (Nazer, 2017). These governmental decisions and policies have very practical implications for Saudi Arabian teachers who now face a wide variety of pressures from the stakeholders involved in the educational process to deliver results in terms of student performance. This may create a conflict in terms of adhering to new curricula, implementing innovative technologies, and at the same time trying to foster critical thinking. The findings of this study may be inapplicable to other countries, limiting the generalisability of the current research; however, they are certainly significant in the Saudi context and may be equality relevant in other similar teaching environments.

The main aim of the study is to identify the most frequently adopted teaching practices for improving the critical thinking skills of Saudi students in secondary schools. Its main objectives are:

1. To identify in the literature the most common teaching practices employed to foster students' critical thinking skills.

2. To identify the most effective teaching practices employed by teachers to develop the critical thinking skills of the secondary school students in the research setting.

3. To examine the extent to which the Saudi teachers believe that their students are able to use critical thinking skills in their studies.

4. To provide Saudi teachers with recommendations on how the students' critical thinking skills could be improved in the classroom.

\section{LITERATURE REVIEW}

\subsection{Models and Definitions of Critical Thinking}

It is believed that critical thinking mainly refers to the cognitive processes related to information processing and evaluation (Salmon, 2013). Through critical thinking, an individual is able to make inferences based on the provided data and evaluate the available knowledge with respect to the dimensions of validity, reliability and generalisability (Salmon, 2013). One critical remark against this definition is that there exist a wide variety of skills, models and approaches to critical thinking, such as induction, deduction and abduction (Black, 2013). However, the overall goal of these models is to establish valuable conclusions and implications from the information available to the inquirer (Black, 2013). 
Another perspective on critical thinking is that this skill serves as a tool for decision-making (Innabi, 2003). This entails that critical thinking is generally seen as an essential skills in cases in which an individual is required to make a choice based on the facts available in the macro-environment (Innabi, 2003). Overall, it can be stated that critical thinking is required both in the academic setting, in which this dimension directly affects learning and comprehension, and in everyday life due to the need to consume and synthesise large amounts of information (Hughes and Lavery, 2015). That said, the success of critical thinking is largely dependent on the cognitive skills and abilities possessed by a particular individual (Hughes and Lavery, 2015). Thus, critical thinking constitutes a mastery, which is achieved through possessing and developing mental capabilities related to understanding as well as by objectively evaluating insights from different sources (Hughes and Lavery, 2015).

Among these competencies, it is possible to distinguish specific micro-skills: having a reflective stance towards all information available on a certain topic, being capable of following a pre-determined approach to logical thinking (be it induction, deduction and abduction), and implementing the outlined processes in practice (Glaser, 1941). The importance of critical thinking skills is high in academic settings in which students are regularly required to reach their own conclusions from the evidence provided by academic sources and teachers (Ennis, 1962). On the other hand, it is admitted that while the aforementioned critical thinking capabilities could be innate, there is a great degree of emphasis on teaching the students to display a higher degree of critical thinking to raise their academic competency and improve their overall life skills (Ennis, 1962).

Critical thinking could be conceptualised through distinct frameworks and models, such as the process-based approach proposed by Nosich (2012) (Figure 1).

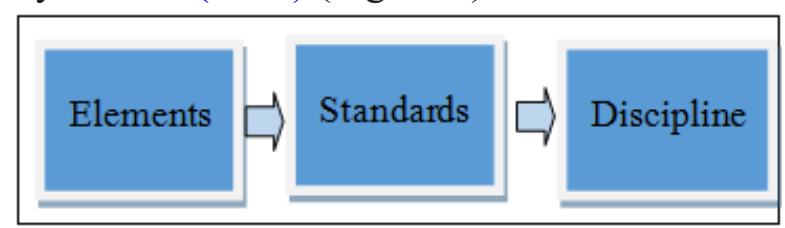

Figure 1. Process-Based Approach to Critical Thinking (Nosich, 2012, p.37)

Nosich (2012) reported on the elements, the procedures related to general cognition and on making inferences from the available data. While these processes form the core of critical thinking, there are also general and discipline-specific standards that serve as filters for the results of the initial critical thinking process. For example, the existing body of knowledge on the subject suggested that the standards may be related to six characteristics, namely background insight, understanding, implementation, evaluation, integration and appraisal (Jackson and Newberry, 2011). The key implication of this result was that in order to display developed critical thinking skills, students had to adhere to strict guidelines regarding the consumption of information (Jackson and Newberry, 2011). In turn, the degree, to which the inquirers were able to elicit their own understanding through the outlined dimensions could be augmented by the academic professionals by employing specific teaching practices and initiatives (Jackson and Newberry, 2011). Nonetheless, since the framework of Nosich (2012) was discipline-specific, it is implied that critical thinking strategies may go beyond the findings reported by Jackson and Newberry (2011). By relying on the discussed models, the study is limited in terms of its explanatory power concerning phenomena related to critical thinking and academic outcomes.

There also exists an alternative approach to modeling critical thinking, which advocates that all inquirers go through six stages of critical thinking mastery (Paul and Elder, 2013). More specifically, such a transformation passed through the phases of being an unreflective, challenged, beginning, practicing, advanced and master thinker (Paul and Elder, 2013). Although this conceptualisation is justified in that it covers the major steps towards critical thinking development, it is ambiguous whether the stages are applicable to all inquirers irrespective of their cognitive abilities (Moon, 2007). Moreover, the framework of Paul and Elder (2013) posited that external influence was required for students to begin developing their critical thinking capabilities. While this may be justified, this would place the motivational focus of learning critical thinking almost entirely on outside factors, such as teachers and the academic curriculum (Moon, 2007). It is unknown whether this is applicable to all possible educational cases, which is why the models of Nosich (2012), and Jackson and Newberry (2011) are adopted as central to the aims and objectives of the study. 


\subsection{Influence of Teaching Practices on Students' Critical Thinking Skills}

Researchers and educators have advocated for some key teaching practices and strategies aimed at improving students' critical thinking. For instance, using mixed educational tactics and flipped classroom models were considered as highly beneficial methods by Smith et al. (2018). The empirical evidence gathered by the researchers suggests that integrating critical thinking strategies into the curriculum of the disciplines was a reasonable way of enhancing students' critical thinking capacities (Smith et al., 2018). A similar result was achieved by placing theoretical lectures outside of regular classroom activities and instead focusing on practical assignments which would traditionally be considered as homework (Smith et al., 2018). Additional support to the above ideas was given by Petek and Bedir (2018) who noted that integrating critical thinking teaching into the school disciplines (e.g. teaching English) was a valid tactic to improve educational outcomes related to critical thinking. Important as the works of Smith et al. (2018) and Petek and Bedir (2018) are, the issue of the applicability of the outlined practices to the setting of this study (Alamri, 2011). It remains an issue due to the cultural and educational differences between their research settings and the Saudi Arabia context.

A different approach towards fostering critical thinking in the academic setting was suggested by Larsson (2017) who focused on phenomenography as a teaching method. Phenomenography was defined as a process of comparing and contrasting different methods of understanding a particular piece of information (Larsson, 2017). Nevertheless, the caveat of the study of Larsson (2017) was that this article only focused on one task. Another unique method of improving students' critical thinking skills was posited by Cargas et al. (2017). The researchers argue that establishing difficult performance tasks across academic disciplines in which the students are faced with a pre-determined problem and are asked to develop their own solutions, works as a positive driver for critical thinking. However, the authors only provide a small sample of performance tasks.

It is also believed that frequently asking evaluative questions in class regarding the current discipline-specific assignments faced by the students could provide the learners with sufficient material and motivation to improve their critical thinking (Browne and Freeman,
2000). This could be expanded further by relying on engagement and active pedagogy. Two possible examples of the teaching practices associated with these dimensions are mentoring (one-to-one teaching) and initiating dialogues with the classroom with the aim of encouraging critical thinking (Gottesman and Hoskins, 2013). The key implication of these arguments is that in order to develop critical thinking capabilities the learners have to be put into academic environments in which individual participation and finding their own resolutions to the classroom tasks are encouraged.

Additional support to the ideas of Browne and Freeman (2000) was provided in the empirical investigation conducted by Boa et al. (2018). It was reported that a dialectic approach called Socratic Questioning was a valuable technique for augmenting students' critical thinking capabilities (Boa et al., 2018) and intellectual independence (Arsić, 2014). More specifically, this paradigm consists of establishing a dialectic environment in the classroom through encouraging student-tostudent and student-to-teacher dialogue and verbal exchange of ideas (Boa et al., 2018). Consistent with the results of the above discussions, there is a substantial body of knowledge confirming that problem-based teaching is beneficial for critical thinking (Carter et al., 2016). Nevertheless, it is also stated that the impact of teaching practices on the skills displayed by the students may be inconsistent due to the influence of mediating factors related to the overall academic environment (Carter et al., 2016).

The literature on teaching practices for critical thinking highlights some practices that are frequently adopted. For example, maintaining a positive classroom atmosphere is cited by Anderson (2004) as a significant influence on the rates of student development, including critical thinking. The teachers are encouraged to foster positive relationships with the students and reformulate their feedback from explicit criticism to positive encouragement (Anderson, 2004). Similarly, Copeland (2005) also noted that students' reaction to verbal praise was highly positive. Through such dialogue between the teacher and the inquirer, the student became more receptive towards the concepts and ideas taught by a specific tutor or within a particular discipline. On the other hand, the interpersonal generalisability of the suggestions made by Anderson (2004) and Copeland (2005) is questionable. For instance, it is possible that some students may pay less attention on the perceptions of the 
teachers and instead be more focused on their self-efficacy.

One critical remark that can be made against the above assertions is that implementing the discussed measures may be challenging and resource-intensive. An example of this was made by Urcola-Pardo et al. (2018) who acknowledged that although activities related to critical thinking were beneficial in the classroom, focusing on these tasks effectively inhibited the students' ability to focus on the demands posited by the regular curriculum. An analogous argument is made by Lee (2018) who reveals that complex behavioural changes were expected from students to increase their critical thinking skills, which could require time and a substantial amount of academic effort. Although the relevance of these shortcomings within the Saudi Arabian sector still remains unknown, the points made above may serve as valid explanations for the findings of this study.

\subsection{Framework of the Study and Research Hypotheses}

Adopting Nosich's (2012) concept of critical thinking as processbased approach, critical thinking mainly consists of elements, standards and discipline-centric factors. These are conceptualised as a sum of factors related to more specific factors: background insight, understanding, implementation, evaluation, integration and appraisal. In this study, critical thinking is also seen as influenced by the teaching practices adopted in the research setting. These methods include, but are not limited to, encouraging dialogue, establishing a positive classroom atmosphere, integrating critical thinking teaching into discipline curricula and providing the students with problemsolving tasks.

Figure 2 provides a graphical overview of the framework of the study.

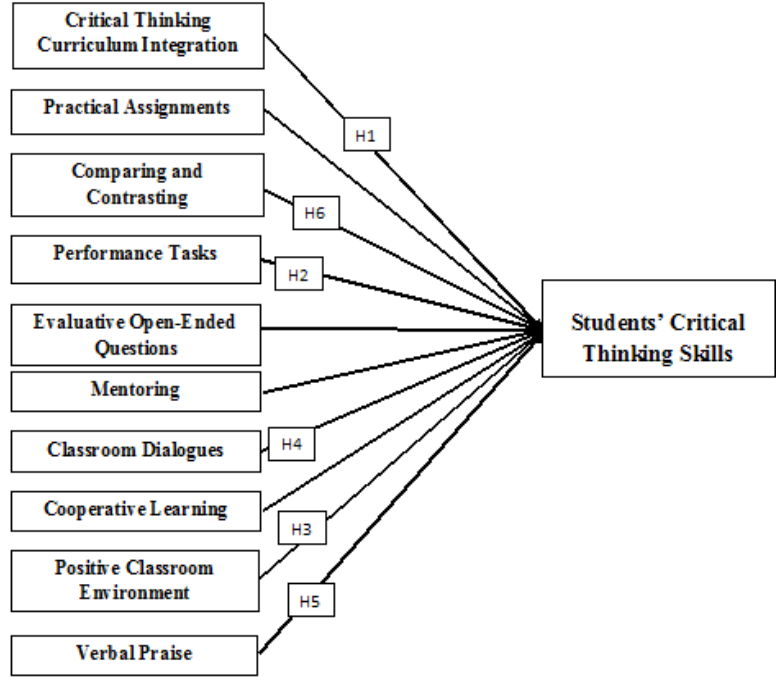

Figure 2. Framework of the Study

The following research hypotheses are formulated on the basis of the above model. Only the most interesting and relevant units of analysis are included in these assertions.

H1: Using mixed educational tactics enhances the students' critical thinking capabilities.

H2: Establishing performance-based tasks enhances the students' critical thinking capabilities.

H3: Establishing a positive classroom atmosphere enhances the students' critical thinking capabilities.

H4: Encouraging dialogue within the classroom enhances the students' critical thinking capabilities.

H5: Relying on positive verbal feedback enhances the students' critical thinking capabilities.

H6: Explicitly comparing and contrasting different points of view enhances the students' critical thinking capabilities.

\section{METHODOLOGY}

\subsection{Data Collection and Sampling}

This study adopted the mixed methods research strategy by distributing a self-administered questionnaire form to the teachers of secondary schools in the Alhafouf region of Saudi Arabia, conducting interviews with selected teachers and observing classroom activities in the secondary schools (Creswell and Creswell, 2017; Bryman and Bell, 2015). In terms of sampling, three schools participated in the project. Eighty two teachers from these schools completed the questionnaire form 
while four teachers from each school out of these 82 respondents were randomly selected for the qualitative interviews and classroom observations. It is admitted that the study follows the non-probability convenience sampling strategy (Daniel, 2012), which may be considered one of the shortcomings of this investigation. Although it is not possible to generalise findings, it is important to mention that the way education is structured in Saudi Arabia has an impact on the general transferability of samples in educational research. This is due to the fact in the highly centralised Saudi educational system; all schools in the country must follow exactly the same curriculum, adopt the same teaching approaches and processes, and employ the same testing instruments and assessment criteria.

In order to increase the reliability of the data collection instruments, the questionnaire and interview questions were revised and adjusted according to the input received by another academic in the field. According to Cohen et al (2011), such steps can potentially increase the internal validity of the research tools. Similarly, a sample of the qualitative and quantitative data analysed was submitted to an experienced academic in the field of education for a reliability check. No significant discrepancy was found in the categorisation or in the analysis of the findings. External validity, on the other hand, could be considered and issue since it is very difficult to generalise the findings of the present study. Instead, I adopt here the concept of transferability (Guba and Lincoln, 2005), which refers to the extent to which the readers of a piece of research can apply its findings to understand their own contexts. As a result, although the generalisability of these findings can be considered low, the potential for transferability to other similar schools in Saudi Arabia and in countries in which cultural background and educational practices are similar may be much higher.

Low levels of reliability, validity and trustworthiness as well as the researcher's bias and lack of rigour (Yin, 2014) have been frequent used as parameters to criticise research based on case studies. However, the triangulation of different types of data (Creswell and Creswell, 2017) can help to address such criticism. In order to reduce unclear interpretations and confirm findings (Punch, 2009), a combination of different quantitative and qualitative means of collecting data (interviews, questionnaire and classroom observations) were used in this study provided the opportunity to compare and confirm the find- ings from different sources. Trustworthiness, reliability, and validity can also be increased by piloting (Newby, 2010) which has aided in the creation of the final versions of the data collection tools.

Ethical issues are directly connect to the integrity of a study and of the disciplines that are involved (Bryman, 2016). Ethical guidelines "are intended to help keep participants safe from harm, build trust with participants and ensure trustworthy outcomes from the research which will benefit society" (Busher and James, 2012, p. 1). In this study, ethical principles were taken into consideration regarding participants' consent, the right to refuse to participate or withdraw at any stage of the study process, and data anonymity and confidentiality.

\subsection{Data Analysis and Variable Definition}

Following the mixed methods research strategy, statistical, graphical and semantic analysis of the primary data were employed in the study (Creswell and Creswell, 2017). The questionnaire responses were converted into bar chart graphs to visualise the most basic trends and patterns in the answers given by the participants. Moreover, the linear regression model was employed to support these findings through statistics and establish cause-andeffect relationships between the established teaching practices and students' critical thinking skills (Montgomery et al., 2012). Only the most important units of analysis are presented from observations and interviews (Saunders et al., 2015). Although integrating different sources of data may lead to contradictory outcomes (Saunders et al., 2015), no significant discrepancy between the quantitative data collected using the questionnaire and the qualitative data from the interviews and classroom observations. On the contrary, the classroom observations showed remarkable coherence between what participants' views of their own practices and what they actually did in the classroom.

The critical thinking teaching strategies identified in the literature review are regarded as the relevant variables in this study and are compiled below in linear regression (Table 1). 
Table 1. Variable Definition

\begin{tabular}{|c|c|c|c|}
\hline $\begin{array}{c}\text { Question } \\
\text { № }\end{array}$ & Variable & Code & $\begin{array}{c}\text { Variable } \\
\text { Type }\end{array}$ \\
\hline 3 & $\begin{array}{l}\text { Open-ended } \\
\text { questions }\end{array}$ & OEQ & Independent \\
\hline 4 & $\begin{array}{l}\text { Cooperative } \\
\text { leaming }\end{array}$ & $\mathrm{COL}$ & Independent \\
\hline 5 & $\begin{array}{l}\text { Mixed meth- } \\
\text { ods leaming }\end{array}$ & MML & Independent \\
\hline 6 & Practical tasks & PRT & Independent \\
\hline 7 & $\begin{array}{l}\text { Comparing } \\
\text { and con- } \\
\text { trasting }\end{array}$ & CAC & Independent \\
\hline 8 & $\begin{array}{l}\text { Performance } \\
\text { tasks }\end{array}$ & PFT & Independent \\
\hline 9 & $\begin{array}{l}\text { Classroom } \\
\text { dialogue }\end{array}$ & CLD & Independent \\
\hline 10 & $\begin{array}{l}\text { Positive } \\
\text { leaming envi- } \\
\text { ronment }\end{array}$ & PLE & Independent \\
\hline 11 & Verbal praise & VBP & Independent \\
\hline 12 & $\begin{array}{l}\text { Mentoring } \\
\text { students }\end{array}$ & MES & Independent \\
\hline 13 & $\begin{array}{l}\text { Students' crit- } \\
\text { ical thinking }\end{array}$ & $\mathrm{SCT}$ & Dependent \\
\hline
\end{tabular}
lows.

The equation for SCT is defined as fol-

$$
\begin{aligned}
& \mathrm{SCT}_{\mathrm{i}}=\alpha_{0}+\beta_{1} O E Q_{\mathrm{i}}+\beta_{2} C O L_{\mathrm{i}}+\beta_{3} M M L_{\mathrm{i}}+ \\
& \beta_{4} P R T_{i}+\beta_{5} C A C_{i}+\beta_{6} P F T_{i}+\beta_{7} C L D_{i}+ \\
& \beta_{8} P L E_{i}+\beta_{9} V B P_{i}+\beta_{10} M E S_{i}+\varepsilon
\end{aligned}
$$

, where SCT denotes the degree, to which the critical thinking skills of the Saudi Arabian students are developed, $\alpha 0$ is a constant, $\beta 1,2,3 \ldots 10$ are the indicators that influence all dependent variables $(i=1,2,3 \ldots 82)$, and $\varepsilon$ marks the residuals.

\section{RESULT}

Statistical data collected through the questionnaires shows that only two variables, namely OEQ and PRT, passed the criterion of statistical significance of Sig. (their p-values) being less than or equal to 0.05 . However, it could be stated that under normal circumstances the p-value benchmark could be expanded to 0.15 , which would mean that the variable in question is statistically significant in at least
$15 \%$ of all cases (Hinton et al., 2014). Considering this, it is also possible to include CAC into the list of the statistically significant units of analysis. Nonetheless, it is acknowledged that the strength of the relationship between CAC and SCT is lower than for OEQ and PRT. The table below shows the results in statistical linear regression analysis (Table 2).

\begin{tabular}{|c|c|c|c|c|c|}
\hline \multirow[t]{2}{*}{ Model } & \multicolumn{2}{|c|}{$\begin{array}{l}\text { Unstandard- } \\
\text { ised Coeffi- } \\
\quad \text { cients }\end{array}$} & \multirow{2}{*}{$\begin{array}{l}\text { Standard- } \\
\text { ised Coeffi- } \\
\text { cients } \\
\text { Beta }\end{array}$} & \multirow[t]{2}{*}{$t$} & \multirow[t]{2}{*}{ Sig. } \\
\hline & B & $\begin{array}{l}\text { Std. } \\
\text { Error }\end{array}$ & & & \\
\hline (Con- & -0.18 & 0.810 & & -0.22 & 0.82 \\
\hline stant) & 3 & & & 6 & 2 \\
\hline \multirow[t]{2}{*}{ OEQ } & 0.297 & 0.125 & 0.279 & 2.376 & 0.02 \\
\hline & & & & & 0 \\
\hline \multirow[t]{2}{*}{$\mathrm{COL}$} & -0.08 & 0.124 & -0.070 & -0.71 & 0.47 \\
\hline & 8 & & & 2 & 9 \\
\hline \multirow[t]{2}{*}{$\mathrm{MML}$} & -0.01 & 0.092 & -0.014 & -0.15 & 0.87 \\
\hline & 4 & & & 5 & 8 \\
\hline \multirow[t]{2}{*}{ PRT } & 0.308 & 0.113 & 0.269 & 2.723 & 0.00 \\
\hline & & & & & 8 \\
\hline \multirow[t]{2}{*}{$\mathrm{CAC}$} & 0.244 & 0.129 & 0.219 & 1.895 & 0.06 \\
\hline & & & & & 2 \\
\hline \multirow[t]{2}{*}{ PFT } & 0.007 & 0.113 & 0.006 & 0.065 & 0.94 \\
\hline & & & & & 8 \\
\hline \multirow[t]{2}{*}{ CLD } & -0.05 & 0.110 & -0.049 & -0.51 & 0.60 \\
\hline & 7 & & & 3 & 9 \\
\hline \multirow[t]{2}{*}{ PLE } & 0.170 & 0.104 & 0.162 & 1.642 & 0.10 \\
\hline & & & & & 5 \\
\hline \multirow[t]{2}{*}{ VBP } & 0.012 & 0.103 & 0.010 & 0.112 & 0.91 \\
\hline & & & & & 1 \\
\hline \multirow[t]{2}{*}{ MES } & 0.082 & 0.093 & 0.079 & 0.881 & 0.38 \\
\hline & & & & & 1 \\
\hline
\end{tabular}

Table 2. The Influence of Teaching Practices on the Students' Critical Thinking Skills

The above findings are interpreted as meaning that positing more open-ended questions in the classroom can improve the critical thinking skills of the students of the secondary schools in the Alhafouf region of Saudi Arabia. Classroom observations confirmed that teachers use of open-ended questions. For example, Teacher 2 asked students in his Maths class, "Why do you think that this principle applies to questions 2 and 6 but to not apply to the other questions related to the problem?" (Teacher 2 , School 4). Such findings are consistent with the outcomes mentioned by Browne and Freeman (2000). While closed-questions require one restricted alternatives with the right and wrong answers being determined by a key or the teacher's set answer; open-questions in- 
stead require learners to analyse the question, evaluate how their knowledge can be relevant to the answer, consider different options and opinions, and then decide on the best possible reply. Furthermore, discussing their possible answer can lead to the reinforcement of the knowledge acquired in the process or a change in perspective with new knowledge being created.

A similar effect was achieved by relying on the dimension of phenomenography and explicitly comparing and contrasting different perspectives and pieces of evidence (Larsson, 2017). An example of this was observed in the Library and Research Module when the teacher asked one student, "What is the best way to search for information?" (Teacher 4, School 1). The student replied that the best way was to search online. The teacher then asked other students if they agreed with him. Different views were presented with some students saying that information online "was not reliable' and it was best 'to use books'. The teacher asked students to discuss their different points of view and then open their textbook and compare and contrast their opinions with the views presented in the text.

In this process, students are asked to examine old and new information, compare diverse input material, and consider different perspectives and representations of reality. Such highly cognitive process can lead to the development of the ability to evaluate sources and points of view and then select the best option and course of action.

Finally, focusing on practical tasks can also enhance the critical thinking capabilities of the learners in the academic setting. Practical tasks typically require students to critically examine their ideas, knowledge and beliefs to achieve the task. For instance, in the English language class, the teacher gave students an exercise on relative clauses and asked them to choose the best relative pronouns to complete the sentences and explain why they have chosen one pronoun over the others. As homework, the teacher gave a similar task and asked students to bring their answer for discussion in the following lesson (Teacher 1, School 3).

However, such important variables as establishing a positive classroom environment or verbal praise were not effective within the chosen study context. One possible explanation for this result arises from the answers provided by the questionnaire respondents. For instance, Figure 2 demonstrates the opinions and perceptions held by the questionnaire sample with regards to the practice of cooperative learning.

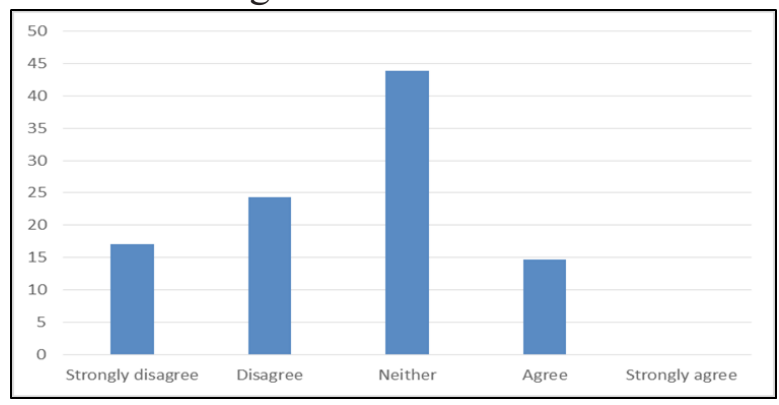

Figure 3. When in the classroom, I encourage cooperative learning (\%)

It is observed that $43.9 \%$ of the respondents failed to provide a definite answer towards the implementation of cooperative learning. Only $14.6 \%$ of the participants of the study agreed with the fact that cooperative learning was encouraged in their classrooms. This could be interpreted as meaning that secondary school teachers in Saudi Arabia in general are still unaware of the benefits of cooperative learning as defined by Boa et al. (2018). On the other hand, this result could also be indicative of the fact that cooperative learning is seen as highly challenging to integrate into the regular classroom activities in the research context. Since the design of the questionnaire survey did not allow for positing additional questions, it is ambiguous, which of the above explanations is valid based purely on the quantitative data. An analogous statement could be made with regards to graphical analysis of such variables as mixed methods learning and one-to-one mentoring.

The qualitative data collected from the interviewees randomly chosen for the study suggests that there is often a dichotomy between participants' views and their classroom practices. Many of the interviewed teachers recognised the importance of critical thinking and were highly aware of the benefits of developing the critical thinking skills of the students, but also emphasised the challenges and problems when trying to embed critical thinking skills into their classroom activities. For instance, Interviewee 1 stated that "critical thinking is one of the major life skills, which is hugely important not only when studying, but also during everyday life and work". Moreover, the definitions of critical thinking provided by the interviewees were frequently aligned with the frameworks of such authors as Nosich (2012). For example, Interviewee 5 stated that "critical thinking is how well you are able to compare and contrast differ- 
ent points of view...critical thinking is also required to make conclusions and inferences on the basis of what is available to students".

In spite of such awareness, the main issues faced by the secondary school academic professionals may constitute a barrier to the application of such ideas. Students' behaviour was cited as one of the key challenges for teaching practice effectiveness. Interviewee 3 argued that "in some cases, students actively refuse to go beyond the school subjects". At the same time, there were highlighted problems related to school curricula and resources. Interviewee 9 argued that "there is a conflict between new methods of teaching, which are focused on critical thinking, and the traditional paradigms of learning followed for a long period of time in Saudi Arabia" while "limited school resources" were also mentioned by Interviewee 5. These assertions were confirmed by the observations made by the researcher. The teachers frequently struggled with controlling students during classes, which hindered their ability to introduce practices related to critical thinking. In addition, the teachers were frequently forced to follow traditional curricula, thus significantly limiting the amount of time allocated to critical thinking development activities. This resulted in many teachers (a total of $65.7 \%$ ) reporting that the critical thinking skills of their students were underdeveloped.

\section{DISCUSSION}

Overall, the findings of this study are consistent with the work of Larsson (2017) who exemplified the role of phenomenology in teaching critical thinking. In addition, the vital role played by practical tasks and openended questions is in line with the key arguments presented by Browne and Free-man (2000), and Cargas et al. (2017). The key implication of these outcomes is that more attention should be devoted to the outlined practices in the secondary schools of Alhafouf. However, other techniques (such as maintaining a positive classroom environment) may also be beneficial. Due to their low popularity in the Alhafouf context, the study was unable to establish whether these teaching initiatives could have a strong effect on the critical thinking skills of the students. It is inferred that secondary school teachers may improve academic outcomes by referring to the teaching strategies, which were attributed with low popularity scores in the current study.
One notable finding is that many participants reported difficulties with the classroom behaviour of their students. This expands the findings of this study beyond the previous works of other researchers such as Smith et al. (2018), and Petek and Bedir (2018). It is asserted that maintaining reasonable classroom discipline can be beneficial for the critical thinking skills of the students. Providing a stable educational environment should give the teachers more opportunities to implement the key techniques aimed at improving the critical thinking skills of their students. Nevertheless, it is difficult to provide specific suggestions regarding this aspect based on the available primary evidence.

The findings of this study also show that school resources and traditional curricula were considered as significant barriers for the implementation of the teaching practices beneficial for critical thinking. This was aligned with the core framework of Nosich (2012) who noted that critical thinking was inseparable from the overall educational environment expressed through the most relevant standards and discipline-related conditions. This finding puts the emphasis on the all stakeholders involved in the educational process to aid teachers in fostering the critical thinking skills of the students instead of positing additional challenges and problems. That said, it remains uncertain and still subject to further research which specific educational strategies or reforms could be implemented by the Saudi Arabian government to achieve such goal.

The overall consensus established in this study was similar to the discussion presented by Salmon (2013). More specifically, it was shown that critical thinking is generally perceived as a highly important cognitive skill directly related to information processing and evaluation. The broader implications of critical thinking (decision-making capacities) are also indirectly supported in the study via the interview transcripts. The participants of this study are aware of the benefits of critical thinking and consciously strive towards developing the mental abilities of their students. This outcome exemplifies the overall importance of critical thinking in the academic setting. On the other hand, this particular outcome may have been caused by the sample composition, which would limit its generalisability. 


\section{CONCLUSIONS AND RECOMMENDATION}

\subsection{Summary of the Findings}

To address the first research objective, it was stated that the critical thinking skills of the students in the academic setting could be developed through particular teaching practices, such as establishing a positive learning environment, mentoring, focusing on practical tasks, positing open-ended questions, comparing and contrasting different perspectives etc. It was suggested that implementing these methods could lead directly to students improving their critical thinking capabilities. Nonetheless, only open-ended questions, comparing and contrasting, and practical tasks passed the benchmarks of statistical significance (Objective 2). This may be explained by stating that the educational process in Saudi Arabia faces significant challenges related to teacher awareness, school resources, school curricula and student discipline. As a result, the critical thinking skills of the students were only evaluated as medium by the surveyed teachers (Objective 3). The development of critical thinking skills goes thus beyond adopting certain classroom teaching practices and is also affected by broader factors related to the academic environment.

\subsection{Evaluation of Hypotheses}

It is necessary to identify which of the research hypotheses found support in the gathered evidence. Only hypotheses 6 and 2 were explicitly justified by the results of the statistical analysis. All other hypotheses were rejected on the basis of the cause-and-effect relationships established via linear regression. The most probable explanations for this outcome was either the lack of awareness among teachers towards the benefits of the teaching practices mentioned in the rejected hypotheses or the influence of the barriers and challenges established previously (e.g. curricula conflict). One critical remark that can be made against this discussion is that since the hypotheses only focused on what was perceived as the most relevant units of analysis, these propositions did not reflect the full picture concerning the development of critical thinking in Alhafouf.

\subsection{Recommendations for the Secondary School Teachers}

Addressing the fourth and final objective of the study, practical recommendations are provided for the teachers employed in the secondary schools at Alhafouf. One of the most important findings of this study was that teaching critical thinking goes beyond the considered teaching practices and is depended on such factors as classroom discipline and school curriculum. Thus, the Alhafouf secondary school teachers should be encouraged to modify their approach with respect to classroom management. For instance, strategies relying on aggressive punishment may be discarded in favour of recognition, understanding and praise, which were considered highly advantageous by Rahimi and Hosseini (2012). On the other hand, the ability of teachers to influence school curricula and resources may be limited since these factors are typically regulated by other academic stakeholders, such as the Saudi government.

Since open-ended questions, phenomenography and performance tasks were considered in the study as the most effective teaching practices, the academic personnel employed at Alhafouf should be encouraged keep relying on these methods when attempting to develop the critical thinking skills of the students. However, it is asserted that the efficiency of such techniques may be further improved by relying on innovative teaching methods and integrating the outlined tactics with these platforms. For example, e-learning can be employed by the Alhafouf teachers in order to improve educational outcomes related to critical thinking (Popovici and Mironov, 2015). That said, the implementation of such solutions may require investing on school resources. It is unknown whether all secondary schools in Alhafouf would be able to follow this recommendation.

\subsection{Limitations of the Study}

It must be acknowledged that the research sample constitutes the most noteworthy limitation of this study. Relying on probability sampling would have been more beneficial with regards to the validity and generalisability of the findings (Saunders et al., 2015). Moreover, this project focused exclusively on the teachers' perspectives and practices and thus lacks a studentcentric perspective with regards to data collection and analysis. While 
the students may be unaware of the complexities of the educational process related to critical thinking, it may be beneficial to gather their perceptions on the teaching practices that can be employed to foster their critical thinking skills. Furthermore, In order to fill in the gap in the literature, future studies could be done in different education stages (elementary and intermediate schools) and in all-female schools to allow academics and teachers to consider possible similarities and differences among learners' thinking skills according to gender.

\section{ACKNOWLEDGEMENTS}

The author acknowledges the Dean-ship of Scientific Research at King Faisal University for the financial support under grant (186002).

\section{Conflict of interests} terest.

The author declares no conflict of in-

\section{REFERENCES}

Alamri, M. (2011). Higher education in Saudi Arabia. Journal of Higher Education Theory and Practice, 11 (4), 88-91. http://www.na-businesspress. com/JHETP/alamri abstract.html

Alaqeel, A. (2013) The policy and system of education in Kingdom of Saudi Arabia. $10^{\text {th }}$ edition. Riyadh: Alroshed. (In Arabic)

Aldiab, A., Chowdhury, H., Kootsookos, A., \& Alam, F. (2017). Prospect of eLearning in higher education sectors of Saudi Arabia: A review. Energy Procedia, 110, 574-580. https://doi. org/10.1016/j.egypro.2017.03.187

Algarfi, A. (2010). Teachers' and pupils' perceptions of and responses to cooperative learning methods within the Islamic culture courses in one secondary school in Saudi Arabia (Doctoral dissertation, University of Southampton). https:// eprints.soton.ac.uk/166259/

Al Ghamdi, A. K. H., \& Deraney, P. M. (2013). Effects of Teaching Critical Thinking to Saudi Female University Students Using a Stand-Alone Course. International Education Studies, 6(7), 176-188. https://doi.org/10.5539/ies.v6n7p176

Allamnakhrah, A. (2013). Learning critical thinking in Saudi Arabia: Student perceptions of secondary pre-service teacher education programs. Journal of Education and learning, 2(1), 197. http:// dx.doi.org/10.5539/jel.v2n1p197

Alothman, M., Robertson, J., \& Michaelson, G. (2017). Computer usage and attitudes among Saudi Arabian undergraduate students. Computers \& Education, 110, 127-142. https://doi.org/10.1016/j. compedu.2017.02.010

Alwadai, M. A. (2014). Islamic Teachers' Perceptions of Improving Critical Thinking Skills in Saudi
Arabian Elementary Schools. Journal of Education and Learning, 3(4), 37. http://dx.doi. org/10.5539/jel.v3n4p37

Al Lily, A. (2018). The bro code of Saudi culture: 1234 bite-sized explanations of how the human body acts in Arabia. $10^{\text {th }}$ edition. Saudi Arabia, Khobar: Self-Published. https://books.google.com. sa/books?id=RrL4DAAAQBAJ\&dq=The+bro + code + of + Saudi + culture: $+1234+$ bite-sized + ex planations + of + how + the + human + body + acts $+\mathrm{i}$ $\mathrm{n}+$ Arabia. $\&$ hl $=$ en $\&$ sa $=$ X\&ved $=0$ ahUKEwjLzK702eDeAhXOtIsKHYxxCr0Q6AEIKTAA

Anderson, L. (2004). Increasing teacher effectiveness. Retrieved March 20, 2018, from http://unesdoc. unesco.org/images/0013/001376/137629e.pdf

Arsić, Z. (2014). Intellectual independence of students in the process of gaining knowledge. International Journal of Cognitive Research in Science, Engineering and Education (IJCRSEE), 2(2), 83-86. Retrieved from http://www.ijcrsee.com/ index.php/ijcrsee/article/view/141

Black, B. (2013). An A to $Z$ of Critical Thinking, London: Bloomsbury. Retrieved from https://books. google.co.uk/books?hl=en\&lr=\&id=SjQSBwA AQBAJ\&oi $=$ fnd\&pg $=\mathrm{PP} 1 \& d q=\mathrm{An}+\mathrm{A}+\mathrm{to}+\mathrm{Z}+\mathrm{o}$ $\mathrm{f}+$ Critical + Thinking \&ots $=\mathrm{j} 3 \mathrm{Wa} 1 \mathrm{cba} I \& \operatorname{sig}=\mathrm{bl}$ 1weaqOfL92LrI3ZVFJUpFGgfw\#v=-onepage\& $\mathrm{q}=\mathrm{An} \% 20 \mathrm{~A} \% 20$ to $\% 20 \mathrm{Z} \% 20$ of $\% 20$ Critical $\% 20$ Thinking\&f $=$ false

Boa, E. A., Wattanatorn, A., \& Tagong, K. (2018). The development and validation of the Blended Socratic Method of Teaching (BSMT): An instructional model to enhance critical thinking skills of undergraduate business students. Kasetsart Journal of Social Sciences, 39(1), 81-89. https:// doi.org/10.1016/j.kjss.2018.01.001

Brookfield, S. (2012). Teaching for Critical Thinking, Hoboken: John Wiley \& Sons. Retrieved from https://books.google.com.sa/books?id $=\mathrm{r} 7 \mathrm{DG} 2 \mathrm{e} 41 \mathrm{pZMC} \&$ printsec $=$ frontcover $\& \mathrm{~d}$ $\mathrm{q}=$ Teaching + for + critical + thinking $+2012 \& \mathrm{~h}$ $1=$ en $\&$ sa $=\mathrm{X} \& \mathrm{ved}=0$ ahUKEwiH0K-LndPdA hVFQRoKHVRHDioQ6AEIKDAA\#v=one page $\& \mathrm{q}=$ Teaching $\% 20$ for $\% 20$ critical $\% 20$ thinking $\% 202012 \& \mathrm{f}=$ false

Browne, M. N., \& Freeman, K. (2000). Distinguishing features of critical thinking classrooms. Teaching in Higher Education, 5(3), 301-309. https:// doi.org/10.1080/713699143

Bryman, A. (2016). Social Research Methods. $5^{\text {th }}$ edition. New York, NY: Oxford University Press Retrieved from https://books.google.com.sa/bo oks? id $=\mathrm{N} 2 \mathrm{zQCgAAQBAJ} \&$ printsec $=$ frontcov er \&dq=Social + Research + Methods $\& h l=e n \& s$ $\mathrm{a}=$ X\&ved=0ahUKEwjY3oas2uDeAhWsp4sK HV3vAPwQ6AEIJzAA\# $\mathrm{v}=$ onepage $\& \mathrm{q}=$ Soci al\%20Research $\% 20$ Methods $\& \mathrm{f}=$ false

Bryman, A. \& Bell, E. (2015). Business Research Methods ( ${ }^{\text {th }}$ ed.).Oxford: Oxford University Press. Retrieved from https://books.google. com.sa/books?hl=en \&lr $=\& i d=17$ u6BwAA QBAJ\&oi=fnd\&pg $=$ PP $1 \& d q=+$ Business $+R$ esearch + Methods $+\&$ ots $=$ AwNnAcTRk\&si $\mathrm{g}=\mathrm{IB} 8 \mathrm{Hvpskg-LmzUxwrRrcQcbyJR4 \& red}$ ir esc $=y \# v=$ onepage $\& \mathrm{q}=\mathrm{Business} \% 20 \mathrm{Re}$ search $\% 20$ Methods $\& \mathrm{f}=$ false

Busher, H., \& James, N. (2012). The ethical framework of research practice. Research methods in educational leadership \& management, 90-104. Retrieved from https://books.google. 
rs/books?hl=sr\&lr=\&id=1FdBAAAQBAJ $\& o i=$ fnd \&pg $=$ PA90 \&dq $=\bar{B}$ usher,+ H. $+\% 26+$ James, + N.+(2012).+The+ethical + framewor $\mathrm{k}+\mathrm{of}+$ research + practice $,+\mathrm{in}+\mathrm{Briggs},+\mathrm{A} .,+\mathrm{C}$ oleman, + M. $+\% 26+$ Morrison, + M. $+($ eds. $)+$ R esearch+Methods+in+Educational+Leadersh ip $+\% 26+$ Management.+3rd+edn.+London:+ SAGE,+90-104.\&ots $=i 2$ whg YqUz9\&sig=-R HGpoEXxBkkGxUMjiSQDJ6KBgQ\&redir $\mathrm{esc}=\mathrm{y} \# \mathrm{v}=$ onepage $\& \mathrm{q} \& \mathrm{f}=$ false

Cargas, S., Williams, S., \& Rosenberg, M. (2017). An approach to teaching critical thinking across disciplines using performance tasks with a common rubric. Thinking Skills and Creativity, 26, 24-37. https://doi.org/10.1016/j.tsc.2017.05.005

Carter, A. G., Creedy, D. K., \& Sidebotham, M. (2016). Efficacy of teaching methods used to develop critical thinking in nursing and midwifery undergraduate students: A systematic review of the literature. Nurse education today, 40, 209-218. https://doi.org/10.1016/j.nedt.2016.03.010

Cohen, L., Manion, L. \& Morrison, K. (2011) Research Methods in Education. $7^{\text {th }}$ edition. London: Routledge. Retrieved from https://books.google.com. $\mathrm{sa} /$ books? $\mathrm{id}=\mathrm{iaQ} 5 \mathrm{DwAAQBAJ} \&$ printsec $=$ fro ntcover\&dq $=\mathrm{Re}+$ search + Methods $+\mathrm{in}+$ Educat on $\& \mathrm{hl}=$ en $\&$ sa $=$ X\&ved $=0$ ahUKEwi7qaOA3O DeAhXjlosKHWJhAhYQ6AEIKTAA\#v=onep age \&q=Re $\% 20$ search $\% 20$ Methods $\% 20$ in $\% 20$ Education $\& \mathrm{f}=$ false

Copeland, M. (2005). Socratic Circles: Fostering Critical and Creative Thinking in Middle and High School. Portland: Stenhouse Publishers. Retrieved from https://books.google.rs/books? $\mathrm{hl}=\mathrm{en} \& \mathrm{lr}=\& \mathrm{id}=\mathrm{rPGPlQ} 8 \mathrm{RgC0C} \& \mathrm{oi}=$ fnd $\& \mathrm{pg}$ $=$ PR $1 \& d q=+$ Socratic + Circles: + Fostering + Cri tical + and + Creative + Thinking + in + Middle + an $\mathrm{d}+$ High + School\&ots $=$ xg7zdls $952 \&$ sig $=$ KItc31B TEauKtHWuq3 83 xSHG 3 I \& redir e $\mathrm{s} \mathrm{c}=\mathrm{y} \# \mathrm{v}=$ on e page $\& \mathrm{q}=\mathrm{S}$ oc rat i c $\% 2 \overline{0}$ Circles $\% 3 \mathrm{~A} \% 20$ Fostering\%20Critical $\% 20$ and $\% 20$ Creative $\% 20$ Thinking\%20in $\% 20$ Middle $\% 20$ and $\% 20 \mathrm{High} \% 20$ School\&f $=$ false

Creswell, J. \& Creswell, J. (2017). Research Design: Qualitative, Quantitative and Mixed Method Approaches $\left(5^{\text {th }}\right.$ ed.). London: SAGE. Retrieved from https://books.google.com.sa/book $\mathrm{s} ? \mathrm{id}=\mathrm{J} 4 \mathrm{w} 5 \mathrm{DwAAQBAJ} \&$ printse $=$ frontcover $\& d q=$ Research + design:+Qualitative, + quantitat ive, + and + mixed + methods + approaches $\&$ hl $=$ en $\&$ sa $=$ X\&ved=0ahUKEwj7yd-VoNPdAhUI0xo KHeg5CasQ6AEIKDAA\# $\mathrm{v}=$ onepage $\& \mathrm{q}=$ Res earch $\% 20$ design $\% 3 \mathrm{~A} \% 20$ Qualitative $\% 2 \mathrm{C} \% 20$ quantitative $\% 2 \mathrm{C} \% 20$ and $\% 20$ mixed $\% 20$ methods $\% 20$ approaches\&f $=$ false

Daniel, J. (2012) Sampling Essentials. London: SAGE. Retrieved from https://books.google.com.sa/bo oks? id=RJC87h4hCvIC\&printsec $=$ frontcover $\& \mathrm{dq}=$ Sampling + Essentials $\& \mathrm{hl}=$ en $\& \mathrm{sa}=\mathrm{X} \& \mathrm{ve}$ $\mathrm{d}=0$ ahUKEwifpc 7eoNPdAhXBx4UKHXiXD p4Q6AEIJjAA\# $\mathrm{v}=$ onepage $\& \mathrm{q}=$ Sampling\%20 Essentials \&f=false

Ennis, R. (1962). A concept of critical thinking. Harvard Educational Review, 32(1), 81-111. Retrieved from http://psycnet.apa.org/record/1963-00458-001

Glaser, E. (1941). An Experiment in the Development of Critical Thinking. New York: Bureau of Publications of Columbia University. Retrieved from https://books.google.com.sa/books?id=aO89A
AAAYAAJ \&dq $=$ An + Experiment $+\mathrm{in}+$ the + Dev elopment + of + Critical + Thinking $\&$ focus $=$ search withinvol-ume \& $\mathrm{q}=\mathrm{An}+$ Experiment $+\mathrm{in}+$ the $+\mathrm{De}$ velopment + of + Critical + Thinking

Gottesman, A. J., \& Hoskins, S. G. (2013). CREATE cornerstone: introduction to scientific thinking, a new course for STEM-interested freshmen, demystifies scientific thinking through analysis of scientific literature. CBE-Life Sciences Education, 12(1), 59-72. https://doi.org/10.1187/ cbe.12-11-0201

Guba, E. \& Lincoln, Y. (2005). Paradigmatic controversies, contradictions, and emerging confluences, in Denzin, N.K. \& Lincoln, Y.S. (eds.) The Sage Handbook of Qualitative Research. London: SAGE, 191-216. Retrieved from https://books. google.com.sa/books?id=AmPgDQAAQBAJ\& printsec $=$ frontcover\&dq $=$ The + Sage + Handboo $\mathrm{k}+\mathrm{of}+$ Qualitative + Research $+2005 \& \mathrm{hl}=\mathrm{en} \& \mathrm{sa}$ =X\&ved=0ahUKEwiBt6_Q3ODeAhXqtI-\%20 sKHTRHDysQ6AEIJzAA\#v=onepage \& $\mathrm{q}=\mathrm{T}$ he $\% 20$ Sage $\% 20$ Handbook $\% 20$ of $\% 20$ Qualitative $\% 20$ Research $\% 202005 \& f=$ false

Hinton, P., McMurray, I. \& Brownlow, C. (2014). SPSS explained, London: Routledge. Retrieved from https://books.google.com.sa/books?id=Q gjAw AAQBAJ\&printsec $=$ frontcover $\& d q=S P S S+\exp$ lained $\& h \mathrm{l}=\mathrm{en} \& \mathrm{sa}=\mathrm{X} \& \mathrm{ved}=0 \mathrm{ahUKEwidjJaMo9}$ PdAhVNKBoKHXCjBZ4Q6AEIJjAA\#v=onep age $\& \mathrm{q}=$ SPSS $\% 20$ explained $\& \mathrm{f}=$ false

Hooks, B. (2010). Teaching Critical Thinking: Practical Wisdom. London: Routledge. Retrieved from https://books.google.com.sa/books?id=tIfcYgE ACAAJ\&dq=Teaching + Critical + Thinking: + Pra ctical + Wisdom $\& h l=$ en $\&$ sa $=X \& v e d=0$ ahUKEw iTg86309PdAhUHxxoKHfylAxwQ6AEIKTAA

Hughes, W., \& Lavery, J. (2015). Critical Thinking: An Introduction to the Basic Skills-Canadian Seventh Edition. Broadview Press. Retrieved from https://books.google.com.sa/books?id=7c6kC QAAQBAJ\&printsec $=$ frontcover $\& \mathrm{dq}=$ Critica 1+Thinking:+An+Introduction+to+the+Basic+ Skills\&hl $=$ en \&sa $=X \& v e d=0$ ahUKEwjX-7 ao 9PdAhVJxIUKHTeDCkoQ6AEIJjAA\#v $=$ onep age \&q $=$ Critical $\% 20$ Thinking $\% 3 \mathrm{~A} \% 20 \mathrm{An} \% 20$ Introduction $\% 20$ to $\% 20$ the $\% 20$ Basic $\% 20$ Skills\&f $=$ false

Innabi, H. (2003). Aspects of critical thinking in classroom instruction of secondary school mathematics teachers in Jordan. In Mathematics Education into the $21^{\text {st }}$ Century Project Proceedings of the International Conference, Czech Republic. Retrieved from http://www.math.unipa. it/ grim/21_project/21_brno03_Innabi.pdf

Jackson, D. \& Newberry, P. (2011). Critical Thinking: A User's Manual. Boston: Cengage Learning. Retrieved from https://books.google.com.sa/bo oks? id $=1 \times$ RIdpBBJkoC\&printsec $=$ frontcover $\& d q=$ Critical + Thinking: $+A+U s e r \% 27 \mathrm{~s}+$ Man ual $\& \mathrm{hl}=$ en $\&$ sa $=X \& v e d=0$ ahUKEwipo $5 \mathrm{KYpd}$ PdAhUO3RoKHSPCDSIQ6AEILTAB $\# \mathrm{v}=$ on epage \&q $=$ Critical $\% 20$ Thinking $\% 3 \mathrm{~A} \% 20 \mathrm{~A} \% 20$ User's\%20Manual\&f=false

Larsson, K. (2017). Understanding and teaching critical thinking-A new approach. International Journal of Educational Research, 84, 32-42. https:// doi.org/10.1016/j.ijer.2017.05.004

Lee, Y. L. (2018). Nurturing critical thinking for implementation beyond the classroom: Implications from social psychological theories of behavior 
change. Thinking Skills and Creativity, 27, 139146. https://doi.org/10.1016/j.tsc.2018.02.003

Montgomery, D. C., Peck, E. A., \& Vining, G. G. (2012). Introduction to linear regression analysis (Vol. 821). John Wiley \& Sons. Retrieved from https://books.google.com.sa/books?id=1SyiRZh09oEC\&printsec $=$ frontcover $\& \mathrm{dq}=$ Introduction + to + Linear + Regression $+\mathrm{A}$ nalysis $\& h \mathrm{l}=\mathrm{en} \& \mathrm{sa}=\mathrm{X} \& \mathrm{ved}=0 \mathrm{ahUKEwiptfu}$ PptPdAhVMOBoKHVT8CQMQ6AEIJjAA\#$\mathrm{v}=$ onepage $\& \mathrm{q}=$ Introduction $\% 20$ to $\% 20 \mathrm{Lin}-$ ear\%20Regression $\% 20$ Analysis\& $\mathrm{f}=$ false

Moon, J. (2007). Critical Thinking: An Exploration of Theory and Practice. London: Routledge. Retrieved from https://books.google.com.sa/ books?id=BOmkEro IGYC\&printsec $=$ frontc over\&dq=Critical+Thinking: + An + Exploratio $\mathrm{n}+\mathrm{of}+$ Theory+and+Practice $\& \mathrm{hl}=\mathrm{en} \& \mathrm{sa}=\mathrm{X} \& \mathrm{v}$ ed=0ahUKEwiKpKi5ptPdAhWPxoUKHeCD5 gQ6AEIJjAA\# $\mathrm{v}=$ onepage \& $\mathrm{q}=$ Critical $\% 20$ Thinking $\% 3 \mathrm{~A} \% 20 \mathrm{An} \% 20$ Exploration $\% 20$ of $\% 20$ Theory $\% 20$ and $\% 20$ Practice $\& \mathrm{f}=$ false

Nazer, F. (2017). Saudi Arabian education reform making real strides. Retrieved March 17, 2018, from http://www.arabnews.com/node/1134706

Newby, P. (2010). Research Methods for Education. Edinburgh: Pearson. Retrieved from https://books. google.com.sa/books?id=3RUAyjH7wUoC\&d$\mathrm{q}=$ Research + Methods + for + Education \&hl=en \& sa=X\&ved=0ahUKEwigpo-U3eDeAhWElYsK HfYvA-MQ6AEISDAF

Nosich, G. (2012). Learning to Think Things Through: A Guide to Critical Thinking Across the Curriculum. Boston: Pearson Higher Education. Retrieved from https://books.google.com.sa/books ?id=8QIrAAAAQBAJ\&dq=Learning + to + Thin $\mathrm{k}+$ Things + Through $:+\mathrm{A}+$ Guide + to + Critical + Th inking + Across + the + Curriculum. + Boston \&hl $=$ en\&sa $=$ X\&ved $=0$ ahUKEwiDxOHwptPdAhVIzYUKHT_DBgkQ6AEIJjAA

Paul, R., \& Elder, L. (2013). Critical thinking: Tools for taking charge of your professional and personal life. Pearson Education. Retrieved from https://books.google.com.sa/books?id=tcuEAA AAQBAJ\&printsec $=$ frontcover $\& \mathrm{dq}=\mathrm{Critical}+\mathrm{T}$ hinking:+Tools+for+Taking + Charge + of + Your + Professional + and + Personal + Life \&hl $=$ en $\& s a=X$ \&ved=0ahUKEwje4s6gp9PdAhWh4IUKHTR ZDroQ6AEIJjAA\#v $=$ onepage \&q $=$ Critical $\% 20$ Thinking $\% 3 \mathrm{~A} \% 20$ Tools $\% 20$ for $\% 20$ Taking $\% 20$ Charge\%20of\%20Your\%20Professional\%20 and $\% 20$ Personal $\% 20$ Life $\& \mathrm{f}=$ false

Petek, E., \& Bedir, H. (2018). An adaptable teacher education framework for critical thinking in language teaching. Thinking Skills and Creativity, 28, 56-72. https://doi.org/10.1016/j. tsc. 2018.02 .008

Popovici, A., \& Mironov, C. (2015). Students' perception on using eLearning technologies. ProcediaSocial and Behavioral Sciences, 180, 1514-1519. https://doi.org/10.1016/j.sbspro.2015.02.300

Punch, K. (2009). Introduction to Research Methods in Education. London: SAGE. Retrieved from https://books.google.com.sa/books?i$\mathrm{d}=1 \mathrm{~B} v \mathrm{MqiaN} 5 \mathrm{EgC} \&$ printsec $=$ frontcover \& $\mathrm{dq}=$ Introduction + to + Research + Methods $+\mathrm{i}$ $\mathrm{n}+$ Education. $\& \mathrm{hl}=\mathrm{en} \& \mathrm{sa}=\mathrm{X} \& \mathrm{ved}=0 \mathrm{ahUK}$ EwimkJDS3eDeAhUvp4sKHYVIAz0Q6A EILjAB\#v=onepage\& $\mathrm{q}=$ Introduction $\% 20$ to $\% 20$ Research $\% 20$ Methods $\% 20$ in $\% 20$

\section{Education.\& $\mathrm{f}=$ false}

Rahimi, M., \& Hosseini, K. F. (2012). EFL teachers' classroom discipline strategies: The students' perspective. Procedia-Social and Behavioral Sciences, 31, 309-314. https://doi.org/10.1016/j. sbspro.2011.12.060

Salmon, M. (2013). Introduction to Logic and Critical Thinking (6th ed.). Boston: Wadsworth. Retrieved from https://books.google.rs/books?hl $=$ sr\&lr $=\& i d=$ vd8JAAAAQBAJ\&oi=fnd $\& p g=$ PR7\&dq=Salmon, + M.+(2013).+Introduction + to + Logic + and + Critical+Thinking $+(6$ th + ed. $) .+$ Boston:+Wadsworth.+\&ots=6pwpQAIevc\&sig

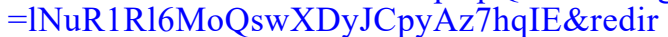
$\mathrm{esc}=\mathrm{y} \# \mathrm{v}=$ onepage $\& \mathrm{q}=$ Salmon $\% 2 \mathrm{C} \% 20 \mathrm{M} . \% 2 \overline{0}$ (2013).\%20Introduction $\% 20$ to $\% 20$ Logic $\% 20$ and $\% 20$ Critical $\% 20$ Thinking $\% 20$ (6th\%20 ed.). $\% 20$ Boston $\% 3 \mathrm{~A} \% 20$ Wadsworth. $\& \mathrm{f}=$ false

Saunders, M., Lewis, P. \& Thornhill, A. (2015). Research Methods for Business Students ( $7^{\text {th }}$ ed.). London: Routledge. Retrieved from https:// books.google.com.sa/books? id =vUdOCgAAQ BAJ\&dq=Research+Methods + for + Business + Students\&hl=en\&sa $=$ X\&ved $=0$ ahUKEwjKu93a qNPdAhUO-YUKHQlfCu8Q6AEIJjAA

Smith, T. E., Rama, P. S., \& Helms, J. R. (2018). Teaching critical thinking in a GE class: A flipped model. Thinking Skills and Creativity, 28, 73-83. https://doi.org/10.1016/j.tsc.2018.02.010

Urcola-Pardo, F., Blázquez-Ornat, I., Anguas-Gracia, A., Gasch-Gallen, Á., \& Germán-Bes, C. (2018). Perceptions of nursing students after performing an individual activity designed to develop their critical thinking: The "critical card" tool. Nurse education in practice, 29, 35-40. https://doi. org/10.1016/j.nepr.2017.11.005

Thomas, G. (2017). How to Do Your Research Project: A Guide for Students. Sage. Retrieved from https://books.google.com.sa/books?id=ucPaA wAAQBAJ\&printsec $=$ frontcover\&dq $=$ How $+\mathrm{t}$ $\mathrm{o}+$ Do + Your+Research ++ Project\&hl $=$ en $\& s a=$ X\&ved=0ahUKEwj9ubGb3uDeAhUEtYsKHf PeC6cQ6AEIJzAA\#v=onepage \& $\mathrm{q}=$ How $\% 20$ to $\% 20$ Do $\% 20$ Your $\% 20$ Research $\% 20 \% 20$ Project\&f $=$ false

Tsankov, N. (2017). Development of transversal competences in school education (a didactic interpretation). International Journal of Cognitive Research in Science, Engineering and Education (IJCRSEE), 5(2), 129-144. https:// doi.org/10.5937/IJCRSEE1702129T

Yin, R. (2014). Case Study Research-Design and Methods. $5^{\text {th }}$ edition. London: SAGE. Retrieved from https://books.google.com.sa/books?id=OgyqB AAAQBAJ\&dq=Case+Study+Research-Desig $\mathrm{n}+$ and + Methods. $\& h \mathrm{l}=$ en $\& \mathrm{sa}=\mathrm{X} \& \mathrm{ved}=0 \mathrm{ahUK}$ EwiY2bfB3uDeAhWHKCwKHbcgCvoQ6AEIMzAC 